\title{
From farm to fork: Human health and well-being through sustainable agri-food systems
}

\section{Ekaterina Arabska ${ }^{1}$}

1 Assoc. Prof. Dr., University of Agribusiness and Rural Development,Plovdiv, Bulgaria, E-mail: earabska@uard.bg

\begin{abstract}
From Farm to Fork Strategy is at the heart of the European Green Deal - the new growth strategy of the EU and a key to the implementation of Sustainable Development Goals (SDGs). From Farm to Fork Strategy is designed for building a fair, healthy and environmentally-friendly food system with an integrated food safety policy in the Union. Current paper presents some of the strategic accents of the main European documents and initiatives concerning future sustainable agri-food systems in the context of human health and well-being through the ecological, economic and social aspects of sustainability. Special attention is also paid to how the future Common Agricultural Policy (CAP) will contribute to the EU Green Deal, food quality and safety, and sustainable development as a whole. Particular examples are presented showing the support to the agriculture and food sectors amid Coronavirus and rural responses to the COVID-19 crisis as collected by the European Network for Rural Development (ENRD). Good practices from Bulgaria are also analyzed regarding the initiatives of promoting local food through farmers' markets and online platforms and new challenges and best solutions. Conclusions focus on the general measures and actions for the effective transition to a fair, healthy and environmentallyfriendly agri-food system.
\end{abstract}

Keywords: Sustainability, Health, Farming, Food, Environment.

JEL codes: I31, Q12, Q18, Q56 


\section{INTRODUCTION}

In contemporary days of some of the most existential threats to Europe and world new growth strategy entitled the European Green Deal gains momentum. Its main goal is to transform the European Union into a resource-efficient and competitive economy with no net emissions of greenhouse gases (GHG) by 2050, decoupling economic growth from resource and caring for each person and place (European Green Deal, 2020). The European Green Deal is accepted as the new plan to make the economy of the EU more sustainable. It will turn climate and environmental challenges into opportunities and make the transition just and inclusive for all. The Green Deal provides an action plan for efficient use of resources and establishing a clean, circular economy restoring biodiversity and cutting pollution. This means huge investments in all the sectors of economy for environmentally-friendly technology; innovation in industry; cleaner, cheaper and healthier transport; decarbonization of energy sector; energy efficient building; and international partnerships to improve global environmental standards. Thus, main policy areas are the following:

- Biodiversity - protection of the fragile ecosystem;

- From Farm to Fork - more sustainable agri-food systems;

- Sustainable agriculture - sustainability in EU agriculture and rural areas (CAP);

- Clean energy;

- Sustainable industry - sustainable, more environmentally-respectful production cycles;

- Building and renovating - a cleaner construction sector;

- Sustainable mobility - sustainable means of transport;

- Eliminating pollution - measures to cut pollution rapidly and efficiently;

- Climate action - making the EU climate neutral by 2050.

So EU has taken on the route of assuring zero pollution, affordable secure energy, smarter transport, highquality food; confident decisions and environmentally responsible projects; new jobs, cleaner environment, better quality of life.
Biodiversity is crucial because nature provides materials, food, health and medicines, recreation and wellbeing for all, for business - half of the Gross Domestic Product (GDP) of the world depends on nature - $€ 40$ trillion. The EU's Biodiversity Strategy will provide the ecological recovery by 2030 combating loss of biodiversity, climate change and spread of devastating pandemics (EU Biodiversity Strategy for 2030, 2020). One of its key elements is restoring degraded ecosystems by increasing organic farming and biodiversity-rich landscape features on agricultural land; halting and reversing the decline of pollinators; reducing the use and harmfulness of pesticides by $50 \%$ by 2030; restoring at least $25,000 \mathrm{~km}$ of EU rivers to a free-flowing state; planting 3 billion trees by 2030, etc. Integrating natural capital and biodiversity considerations into business practices will also be a main issue in the EU's recovery plan from coronavirus pandemic with business and investment opportunities for the EU's economy in three key economic sectors: construction; agriculture; food and drink which are highly dependent on nature. On the other side, this will mean direct and indirect local jobs and revitalization of local communities.

Because a healthier and more sustainable EU food system is a cornerstone of the European Green Deal, From Farm to Fork Strategy presents the ways to ensure more sustainable food systems (From Farm to Fork: Our Food, Our Health, Our Planet, Our Future, 2020):

- securing access to healthy, affordable and sustainable food;

- tackling climate change;

- protecting the environment and preserving biodiversity

- ensuring a fair economic return in the supply chain;

- increasing organic farming.

- Targets for 2030 are connected to the following main issues:

- reducing the use of chemical and more hazardous pesticides by $50 \%$;

- reducing nutrient losses by at least 50\% while ensuring no deterioration on soil fertility;

- reducing fertilizer use by at least $20 \%$; 
- reducing the sale of antimicrobials for farmed animals and in aquaculture by $50 \%$;

- increasing organic farming sector with the goal of $25 \%$ of total farmland to be used for organic farming by 2030 .

Table 1. Important steps in Farm to Fork Strategy

\begin{tabular}{|c|c|}
\hline $\begin{array}{l}\text { - Creating a food environment that } \\
\text { makes the healthy and sustainable } \\
\text { choice the easy choice }\end{array}$ & $\begin{array}{l}\text { The risk of life-threatening diseases can be reduced by the healthy diets which } \\
\text { also reflect on the environmental impact of the food system. }\end{array}$ \\
\hline $\begin{array}{l}\text { Adding food labels that allow } \\
\text { consumers to choose healthy and } \\
\text { sustainable diets }\end{array}$ & $\begin{array}{l}\text { A sustainable food-labeling framework covering environmental and social } \\
\text { aspects of food products and mandatory front-of-pack nutritional information. }\end{array}$ \\
\hline $\begin{array}{l}\text { - Stepping up the fight against food } \\
\text { waste }\end{array}$ & To cut food waste by half across the EU by 2023 . \\
\hline - Research and innovation & $\begin{array}{l}\text { Knowledge transfer will be the key to the transformations. } € 10 \text { billion } \\
\text { under Horizon Europe are expected to be invested in R\&I related to food, } \\
\text { bioeconomy, natural resources, agriculture, fisheries, aquaculture and } \\
\text { environment. New incentives are designed for CAP's farm advisory services } \\
\text { and farm sustainability data network. }\end{array}$ \\
\hline $\begin{array}{l}\text { Promoting the global transition: a } \\
\text { global move towards sustainable } \\
\text { food systems }\end{array}$ & $\begin{array}{l}\text { Sustainability of food can be a competitive advantage and open new business } \\
\text { opportunities for European farmers. The consumers' choice can be facilitated } \\
\text { by the sustainable food labeling framework. }\end{array}$ \\
\hline
\end{tabular}

The strategy is tightly connected to Common Agricultural Policy (CAP) which "pushes for sustainability in agriculture and rural areas across the EU" aiming to ensure that agriculture and forestry in the EU are socially, economically and environmentally sustainable (Sustainable Agriculture in the EU, 2020).

Current paper analyzes-strategic directions in terms of building sustainable agri-food systems assuring human health and well-being.

\section{FROM FARM TO FORK: FOR A FAIR, HEALTHY AND ENVIRONMENTALLY- FRIENDLY FOOD SYSTEM}

Farm to Fork Strategy is at the heart of the European Green Deal because the sustainably-produced and quality food is vital not only for addressing climate change and pollution but also for food producers and public health (Farm2Fork, 2020). In this context this initiative for policy changes and new investments will transform the ways of consumption, production and distribution of food. This means that food systems will become fair, healthy and environmentally-friendly (Farm to Fork Strategy - For A Fair, Healthy And Environmentally-Friendly Food System, 2020) bringing new opportunities for operators in the food value chain so as all stakeholders will be benefiting of new technology and research along with increasing public awareness and demand for sustainable food.

The Farm to Fork Strategy has the main goal to accelerate the transition to a sustainable food system which will:

- have a neutral or positive environmental impact;

- help to mitigate climate change and adapt to its impacts;

- reverse the loss of biodiversity;

- ensure food security, nutrition and public health, making sure that everyone has access to sufficient, safe, nutritious, sustainable food;

- preserve affordability of food while generating fairer economic returns, fostering competitiveness of the EU supply sector and promoting fair trade.

Regulatory and non-regulatory initiatives were set with the common agricultural and fisheries policies as key tools to support the just transition. 
Figure 1. Farm to Fork Strategy - For A Fair, Healthy and Environmentally-Friendly Food System

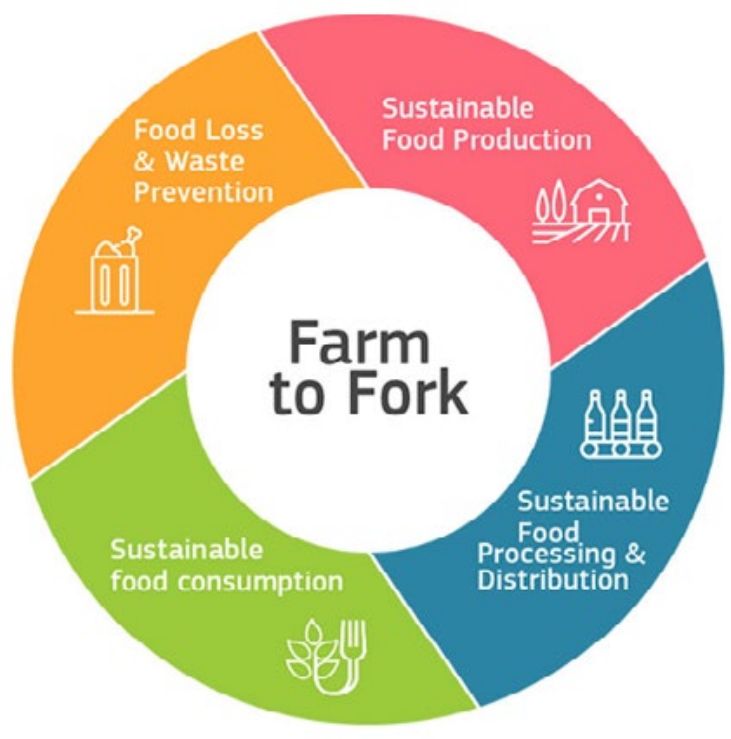

Source: Farm to Fork Strategy - For A Fair, Healthy and Environmentally-Friendly Food System, https:/ / ec.europa.eu/food/ farm2fork en/

We should also bear in mind that food systems cannot be resilient to crises (as the Covid-19) if they are not sustainable. So we have to redesign the agri-food systems, but also to support the global transition through new trade policies and international cooperation instruments.

This transition to a fair, healthy and environmentallyfriendly food system will need new advisory services and financial instruments, research and innovation actions to resolve the problems, develop and test solutions, overcome barriers and uncover new market opportunities.

From Farm to Fork Strategy (Sustainable Food Production, 2020):

- aims to reduce the environmental and climate impact of primary production whilst ensuring fair economic returns for farmers, fishers and aquaculture producers;

- sets targets to significantly reduce the use and risk of chemical pesticides, the use of fertilizers and sales of antimicrobials as well as increase agricultural land under organic farming;

- seeks to improve animal welfare, protect plant health and promote adoption of new green business models, circular bio-based economy and the shift to sustainable fish and seafood production;

- foresees key actions in order to ensure sustainable food production.

One of the main goals is reducing overall environmental footprint of food system and making the adoption of healthy diets easier so the strategy will encourage food industry to increase the availability and affordability of healthy and sustainable food (Sustainable Food Processing, Wholesale, Retail, Hospitality And Food Services, 2020). Actions will be taken to expand and promote sustainable production methods and circular business models in food processing and retail focusing specifically on small and medium-sized enterprises (SMEs).

Sustainable food processing and distribution will embrace the following actions: initiatives of improving the corporate governance framework, incl. requirements for the food industry to integrate sustainability into corporate strategies; developing an EU code and monitoring framework for responsible business and marketing conduct in the food supply chain; reformulation of processed food and setting of maximum levels for certain nutrients; elaborating nutrient profiles for restriction on promotion of food high in salt, sugars and/or fat; a number of proposals for revision of EU legislation as food contact materials to improve food safety, ensure citizens' health and reduce the environmental footprint of the sector and EU marketing standards for agricultural, fishery and aquaculture products to ensure the uptake and supply of sustainable products, as well as ensuring the coordination for enforcing single market rules and combating food fraud.

Farm to Fork Strategy is also for improving the availability and the price of sustainable food and promoting adoption of healthy and sustainable diets by consumers. This means improving consumer information, strengthening sustainable food procurement and encouraging adoption of fiscal measures that support sustainable food consumption (Sustainable Food Consumption and Facilitating The Shift Towards Healthy, Sustainable Diets, 2020). Enabling consumers to make health and conscious food choices means some new initiatives in nutrition labeling and origin indication; encouraging sustainable food procurement for promoting healthy and sustainable diets, incl. organic products, e.g. in 
schools and public institutions, etc.

Another important point to address is reducing food waste which has an enormous potential for efficient resource use because it saves food for human consumption; brings savings for primary producers, companies and consumers; and lowers the environmental and climate impact of food production and consumption (Food Loss and Waste Prevention, 2020).

From Farm to Fork Strategy "addresses comprehensively the challenges of sustainable food systems and recognizes the inextricable links between healthy people, healthy societies and a healthy planet" (A Farm to Fork Strategy: For A Fair, Healthy and Environmentally-Friendly Food System, 2020). Being the key part of the European Green Deal as the new sustainable and inclusive growth strategy, it will contribute to boosting the economy, improving health of people and life quality, care of nature and humans. This strategy is also in the center of the European Commission's agenda to achieve the United Nations' Sustainable Development Goals (SDGs). The last coronavirus pandemic provided some new clues about interrelations between health, ecosystems, supply chains, consumption patterns and planetary boundaries, i.e. underlined the significance of a robust and resilient food system.

The strategy is accepted as a new comprehensive approach to value food sustainability and as an opportunity to improve lifestyles, health and environment, i.e. the favorable food environment will ease the choice of health and sustainable diets contributing to human health and better quality of life. Moreover, the transition to sustainable food systems could be viewed as a huge economic opportunity while at the same time achieving the new climate and environmental objectives. There is no choice between enough nutritious and affordable food for everyone and the protection of future of our planet for our generations.

Building the food chain that works for consumers, producers, climate and the environment means that we will:

- ensure sustainable food production through human and financial investment, new green business models, circular bio-based economy, renewable energy;

- food security as a common European response to crises affecting food systems;

- stimulate sustainable food processing, wholesale, retail, hospitality and food services practices;

- promote sustainable food consumption and facilitate the shift to healthy, sustainable diets;

- reduce food loss and waste

- combat food fraud along the food supply chain.

Figure 2. Building the Food Chain That Works For Consumers, Producers, Climate And The Environment

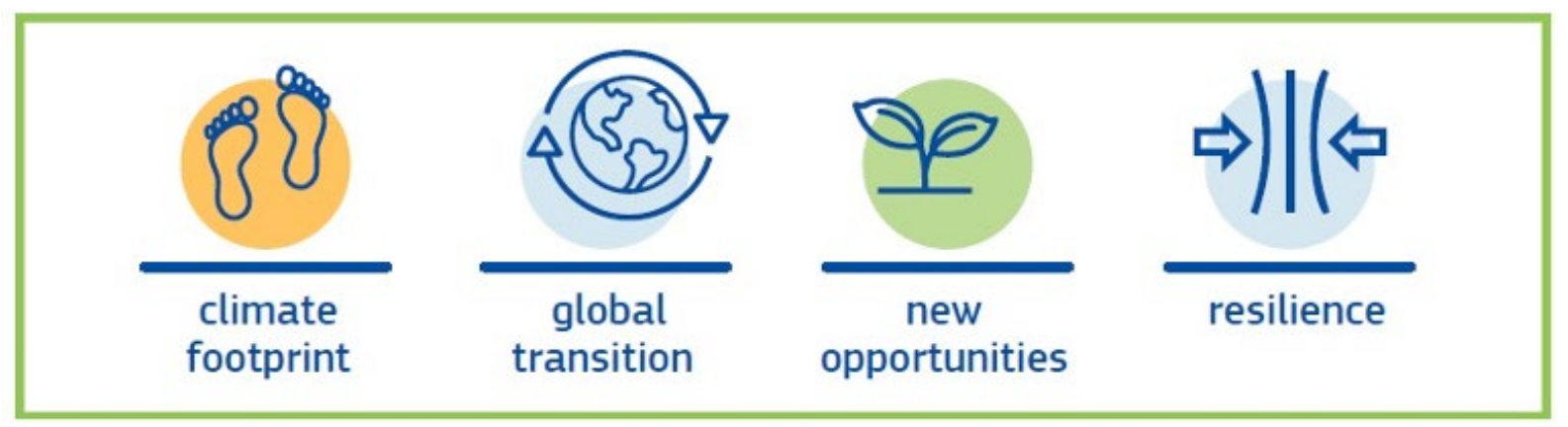

Source: Farm to Fork Strategy (2020), https://ec.europa.eu/food/sites/food/files/safety/docs/f2f action-plan_2020 strategy-info en.pdf

The goals to reduce the environmental and climate footprint of food system and strengthen its resilience, ensure food security in the face of climate change and biodiversity loss and lead a global transition towards competitive sustainability embrace numerous impacts: 
- food chain (incl. food production, transport, distribution, marketing and consumption) will have a neutral or positive environmental impact, preserving and restoring land, freshwater and seabased resources on which the food system depends;

- mitigating climate change and adapting to its impacts;

- protecting land, soil, water, air, plant and animal health and welfare;

- reversing loss of biodiversity;

- ensuring food security, nutrition and public health making sure that everyone has access to sufficient, nutritious, sustainable food that upholds high standards of safety and quality, plant health, and animal health and welfare, while meeting dietary needs and food preferences;

- preserving the affordability of food, while generating fairer economic returns in the supply chain, so that ultimately the most sustainable food also becomes the most affordable;

- fostering the competitiveness of the EU supply sector, promoting fair trade, creating new business opportunities, while ensuring integrity of the single market and occupational health and safety.

From Farm to Fork Strategy considers the sustainability of food systems as a global issue and will support sustainable agri-food systems according to Sustainable Development Goals (SDGs). As part of the EU's Green Deal it can be concluded that the common goal is to make the EU food system a global standard for sustainability and food safety.

Farm to Fork measures intend to assure a high level of food safety and animal \& plant health while ensuring an effective internal market and adequate monitoring (Integrated Food Safety Policy in The EU, 2020). The implementation of this integrated Food Safety policy in the EU means:

- building and effective control system; evaluating the compliance with the EU standards in food quality and safety, animal welfare, animal nutrition and plant health;

- managing international relations with nonEU countries and international organizations concerning food safety, animal health, animal welfare, animal nutrition and plant health;

- ensuring science-based risk management.

The main goal of that policy is to ensure a high level of protection of human health regarding the food industry. As set out in the White Paper on Food Safety, the guiding principle is to apply an integrated approach from farm to fork covering all sectors of the food chain. The White Paper on Food Safety (2020) reflects the priority of the European Commission the EU has the highest standards of food safety. The White Paper sets out: principles of food safety; essential elements of food safety policy: information gathering and analysis - scientific advice; establishing a European food authority; regulatory aspects; controls; consumer information and international dimensions.

Its guiding principles could be summarized as follows:

- a comprehensive, integrated approach embracing the pillars of food safety contained in this White Paper - scientific advice, data collection and analysis, regulatory and control aspects as well as consumer information;

- the roles of all stakeholders in the food chain;

- the traceability of feed and food and their ingredients;

- a more coherent, effective and dynamic food policy;

- expanding the level of transparency;

- risk analysis as the foundation on which food safety policy is based;

- the best available science in developing food safety measures;

- the precautionary principle to be applied in risk management decisions;

- other legitimate factors relevant for the health protection of consumers and for the promotion of fair practices in food trade also should be taken into account.

The White Paper is the basis to transform the EU's food policy into "a proactive, dynamic, coherent and comprehensive instrument" to ensure a high level of human health and consumer protection. The 
implementation of White Paper's measures will enable food safety to be organized in a more co-ordinated and integrated manner in order to achieve the highest possible level of health protection, as well as to ensure a greater transparency and consumers' confidence in EU food policies.

Another important issue is the future CAP which will make the agricultural policy more responsive to current and future challenges, while continuing to support the active needs of European farmers (The future of CAP, 2020). The new policy is set as more intuitive and innovative with the goal to encourage a sustainable and competitive agricultural sector in the EU. The proposals include the need of a strong support to farming in Europe for prosperous rural areas and the production of high-quality food. They are meant to make a significant contribution to the European Green Deal, especially with regard to the Farm to fork strategy and Biodiversity strategy and focus on:

- securing a fair deal and a stable economic future for farmers;

- setting higher ambitions for environmental and climate action;

- safeguarding agriculture's position at the heart of Europe's society.

- The future CAP proposals are based on the following key points:

- Better targeting for a fairer deal - real support to real farmers;

- Higher green ambitions - environmental impacts and sustainability;

- A new green architecture - eco-schemes and tools;

- Farmers at the heart of Europe's society - new generations and social development;

- A new way of working - shifting the emphasis from rules and compliance towards results and performance;

- An updated EU-wide framework - actions and result indicators;

- CAP strategic plans - according to the specific needs;

- Benefits of the new way of working: a more effective delivery model, greater flexibility, streamlined administration, stronger environmental protection;

- Boosting innovation - successful AKIS strategies;

- A strong budget and additional flexibilities for certain specific purposes.

The nine key objectives are focused on social, environmental and economic goals and will be the ground upon which EU countries will design their CAP strategic plans (Key Policy Objectives of The Future CAP, 2020):

- Ensure a fair income for farmers - support viable farm income and resilience across the Union to enhance food security;

- Increase competitiveness - increase competitiveness and agricultural productivity in a sustainable way to meet the challenges of higher demand in a resource-constrained and climate uncertain world;

- Rebalance the power in the food chain - improve farmers' position in the value chain;

- Climate change action - contribute to climate change mitigation and adaptation, as well as sustainable energy;

- Environmental care-foster sustainable development and efficient management of natural resources such as water, soil and air;

- Preserve landscapes and biodiversity - contribute to the protection of biodiversity, enhance ecosystem services and preserve habitats and landscapes;

- Support generational renewal - modernize the agricultural sector by attracting young people and improving their business development;

- Foster vibrant rural areas - promote employment, growth, social inclusion and local development in rural areas, including bio economy and sustainable forestry;

- Protect food and health quality - improve the response of EU agriculture to societal demands on food and health, including safe, nutritious and sustainable food, reducing food waste, as well as animal welfare. 
Figure 3. The Specific Objectives of The New CAP

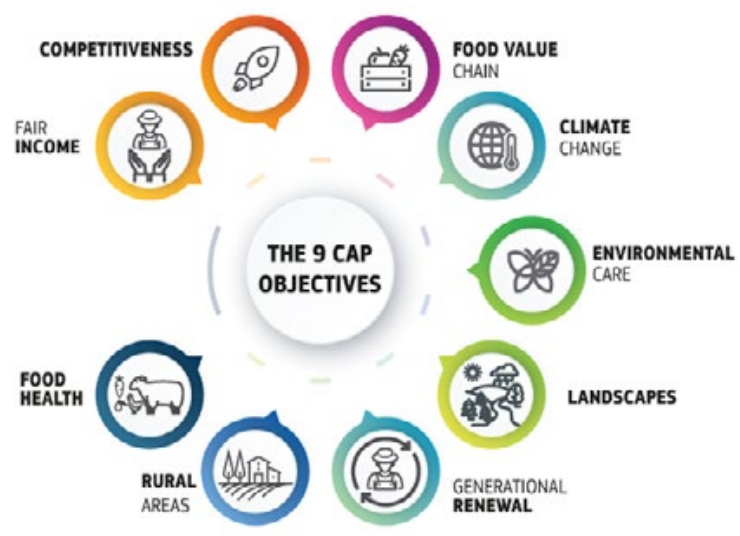

As a cross-cutting objective fostering knowledge, innovation and digitalization in agriculture was also identified (EU Agriculture in Numbers. Performance on the nine specific objectives of the CAP, 2020).

Another main objective is also connected to modernizing and simplifying the CAP and challenges for agriculture and rural areas which were identified as the:

- Economic challenges facing EU agriculture following (Modernizing and Simplifying the CAP, 2020a):

» pressures on farm income;

» weaknessesin productivity and competitiveness;

» imbalance in value chains;

- Climate and Environmental challenges facing EU agriculture and rural areas following (Modernizing and Simplifying the CAP, 2020b):

» climate change;

» unsustainable management of natural resources;

» loss of nature and landscapes;

- Socio-Economic challenges facing agriculture and rural areas following (Modernizing and Simplifying the CAP, 2020c):

» Low growth, under-employment, poor generational renewal;

» Sub-optimal infrastructures and services;

» Territorial imbalance, social inclusion and poverty.

CAP plays a crucial role in supporting the agricultural sector in Europe, even now in the conditions of the coronavirus pandemic putting a great pressure on the resilience of farmers (Analysis of links between CAP Reform and Green Deal, 2020). The legislative proposals concerning the new CAP intend for an agricultural policy:

- to foster a smart, resilient and diversified agricultural sector ensuring food security;

- to bolster environmental care and climate action and to contribute to the environmental - and climate- related objectives of the Union;

- to strengthen the socio-economic fabric of rural areas.

The above-mentioned specific objectives reflect those and cover all the dimensions of sustainability economic, environmental and social, and also the crosscutting objective of knowledge and innovation. This fits to the focus of the European Green Deal regarding:

- Increased contribution of EU agriculture to climate change mitigation and adaptation;

- Improved management of natural resources used by agriculture, such as water, soil and air;

- Reinforced protection of biodiversity and ecosystem services within agrarian and forest systems;

- Effective sustainability of food systems in accordance with societal concerns regarding food and health on e.g. animal welfare, use of pesticides and antimicrobial resistance;

- Ensuring a fair economic return and improving the position of farmers in the food supply chain.

The Green Deal underlines that the Commission will work with the Member States and stakeholders to assure that national strategic plans for agriculture fully reflect the ambition of the Green Deal, the Farm to Fork Strategy and the Biodiversity Strategy, and that those will be assessed by robust climate and environmental criteria. The Green Deal will increase the use of sustainable practices, such as precision agriculture, organic farming, agro-ecology, agro-forestry and stricter animal welfare standards and will also focus on some specific measures as eco-schemes for rewarding farmers for improved environmental and climate performance, incl. carbon management and storing in the soil and improvements in nutrient management for improving water quality and reducing emissions. 
Figure 4. The future CAP and its contribution to the EU Green Deal

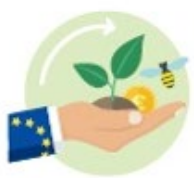

Enhanced conditionality

Conditionality links EU-funded income support to environment- and climatefriendly farming practices and standards.

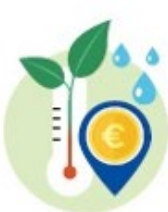

\section{Eco-schemes}

Eco-schemes will unlock new funding and additional incentives for climate- and environment-friendly farming practices.

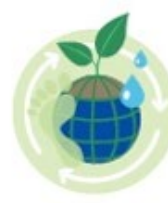

Agri-environment-climate measures and investments

EU rural development support will aim to enhance ecosystems, promote resource efficiency, and help us move towards a lowcarbon, climate-resilient economy.

\section{Farm Advisory Service}

The farm advisory system will draw on a fuller range of economic and environmental data to deliver up-to-date technological and scientific information to advise farmers.

Source: How the future CAP will contribute to the EU Green Deal (2020), https://ec.europa.eu/info/sites/info/files/food-farming-fisheries/ sustainability and natural resources/documents/factsheet-how-cap-contributes-to-green-deal en.pdf/

The more results-oriented delivery model based on strategic planning at member state level, enhanced mandatory requirements and the improved range of voluntary funding tools provide the appropriate framework for the CAP reform proposals to support the European Green Deal. Each member state will make analyses of the situation through analyses of strengths, weaknesses, opportunities and threats (SWOT) and related needs and will make a CAP strategic plan in accordance to the specific requirements and "the new green architecture" is expected to make the significant contribution to the environmental and climate goals. Another important question is that of Agricultural Knowledge and Innovation Systems (AKIS) and farm advisory services to support farmers in making "the most sustainable management choices for the specific location and situation of their farm". What is important for the future CAP is the increased ambition regarding environmental-and climate related objectives ("No backsliding" principle); ring-fenced spending on the environment and climate; data collection and common approach to data; fostering the position of farmers in the food chain, etc.

\section{SUPPORTING THE AGRICULTURE AND FOOD SECTORS IN CORONAVIRUS OUTBREAK AND RESPONSES TO THE COVID-19 CRISIS}

Now, when the whole world, and particularly Europe, is experiencing the consequences of the coronavirus pandemic the agri-food sector is facing a number of obstacles and an increasing pressure on its resilience. One of the EU's top priorities in maintaining food security in this situation and the Commission has taken some important actions for (Supporting the Agriculture and Food Sectors Amid Coronavirus, 2020):

- an efficient food supply chain and a strong food security;

- direct support to farmers and rural areas;

- exceptional market measures;

- CAP simplification and increased flexibility measures.

Some examples include the "green lanes" at key border crossing points and determining seasonal workers as 'critical workers' to secure food sector support, direct support as loans or guarantees for operational costs, flexibility in the use of financial instruments under rural development, etc. Furthermore, the Commission proposes new rural development measure and higher advances of payments. Among exceptional market measures are the private storage aid for dairy and meat products, temporary derogation from EU competition rules and flexibility in the implementation of market support programs for wine, fruits and vegetables, table olives and olive oil, apiculture and the EU's school scheme (covering milk, fruit and vegetables). The last will also allow the re-orientation of funding priorities towards crisis management measures. Regarding CAP flexibility such measures include extension of deadline for CAP payment applications and fewer farm on-the-spot checks. 
In rural areas farmers, business and communities are particularly affected by the outbreak of COVID-19 posing also serious challenges to their socio-economic system (Rural Responses to the COVID-19 Crisis, 2020). There are many examples of projects and initiatives by rural community supporting rural businesses and encouraging solidarity in coping with the COVID-19 emergency. The European Network for Rural Development (ENRD) as a hub for exchange of information shows some of these. Below they are presented in several main categories.

Table 2. Examples Provided by The European Network For Rural Development (ENRD) For Rural Responses To The COVID-19 Crisis

\begin{tabular}{|c|c|}
\hline & $\begin{array}{l}\text { - EIP-AGRI strengthening agricultural resilience in the context of COVID-19: support in terms of strength, } \\
\text { resilience and adaptability of short food supply chains, adapted to local conditions that provide consumers with } \\
\text { nutritious, seasonal foods for which farmers are paid a fair price while ensuring that food systems continue to } \\
\text { function when borders were closed. } \\
\text { - RuralGustos - the taste of rural Romania: To respond to the COVID-19 crisis, the Romanian LAG Dunarea de } \\
\text { Sud set up an online platform, RuralGustos, to promote local food producers and facilitate the dialogue with the } \\
\text { customers. } \\
\text { - Promoting local food through online platforms: experiences across the EU - similar practices in Italy, Hungary, } \\
\text { France and Spain for establishing online platforms for local food producers and connections with the consumers. } \\
\text { - A drive-in to buy local food in Belgium: The cooperative Point Ferme in Belgium supported by LAG Pays de } \\
\text { Condruses setting up a drive-in service to sell locally grown food. } \\
\text { - 'Local heroes' wanted to promote Dutch local food: In the Netherlands, a new online platform allows people to offer } \\
\text { help in producing and promoting local food, to combat the feeling of insecurity generated by the COVID-19 crisis. } \\
\text { People can sign up to the platform and volunteer as promoters (on- and off-line) or 'flexible workers' to support } \\
\text { food producers and customers. } \\
\text { - Italian families help each other and support local food producers: Delivery of locally produced food (fruits, } \\
\text { vegetables, flour, cheese and other) at home for families in need. } \\
\text { - Rural Portugal: initiatives against COVID-19: Rural businesses, Local Action Groups and farmers in Portugal } \\
\text { are mobilising to face the COVID-19 crisis. Initiatives include an online platform to foster local food consumption, } \\
\text { rural beer and spirits companies producing hand sanitising gels and farmers helping spray disinfectants on streets. } \\
\text { These and more initiatives are collected in the latest newsletter by the Portuguese Rural Network. }\end{array}$ \\
\hline
\end{tabular}


Support to information provision and awareness

- The Spanish Authorities response to the COVID-19 crisis: The special support and emphasis placed on the explanation and dissemination of all the available information favored a reorientation and modification of the Spanish RDP's processes to adapt to the new and unforeseen context. The adaptation to this new way of working, specifically in the case of the National Rural Network (NRN), not only proved successful, but also reinforced participation and interest in their activities.

- COVID-19 and food security logistics - online consultation: FAO (Food and Agriculture Organization of the United Nations) has launched an online consultation to collect examples, best practices and case studies of how the impact of the COVID-19 containment measures on food security and agriculture are being managed in different countries from a logistical point of view.

- Supporting mountain agriculture during the COVID-19 crisis: EuroMontana has collected a series of experiences of farmers, local authorities and other rural development stakeholders in mountain areas who are adapting their practices to face the COVID-19 crisis. The page aims at sharing experiences and inspiring other mountain actors to help them overcome the current challenges.

- An online tour of a Flemish community farm: As physical guided tours were not possible due to the COVID-19 outbreak, an organic farm in Flanders (Belgium) has organised a virtual tour of its premises for interested people and potential clients.

- European 'food heroes': Food Drink Europe is collecting examples of its members' activities in the face of COVID-19. These are shared on a website and in an A-Z document. Food and Drink Europe represents the food and drink industry, which buys $70 \%$ of all European farm produce.

- COVID-19 response: the role of platforms, commons and fablabs. European Commisson's DG GROW (Directorate General for Internal Market, Industry, Entrepreneurship and SMEs) is collecting best practices from social economy and civil society in the fight against the coronavirus.

- The European Food Forum's views on the COVID-19 crisis: The European Food Forum (EFF) summarised its members' exchange of views on the impact of COVID-19 on the Food Supply Chain, held in a video conference in early April 2020 and further written contributions.

- A rural Hackaton against the COVID-19 crisis: On 8 April, rural actors in Spain organized a Rural Hackaton considering the economic problems which COVID-19 causes. The event was online presented some initiatives in connection to the economic consequences of COVID-19 in rural communities in Spain.

- Farnet is collecting actions to support the fisheries and aquaculture sector in EU during the crisis: to support the fisheries and aquaculture sector in EU Member States in the COVID-19 crisis.

- COVID-19 Information Hub in Scotland: The Scottish Rural Network has set up an online Information Hub which is updated daily with the latest official guidance, helpful resources, funding support and news relevant to Scotland's rural communities.

- Italian LAG initiatives during the COVID-19 pandemic: A report by the Italian NRN gathers good practices and solutions by Local Action Groups (LAGs) in Italy to face the challenges of the COVID-19 pandemic. To respond to the crisis and prepare the aftermath, LAGs can further develop their work on a variety of topics, including: basic services, neighborhood shops, social innovation, production and marketing networks, sharing economy, bioeconomy and circular economy, smart villages, experiential and sustainable tourism. LEADER offers opportunities for community projects and also umbrella projects. The keywords should be continuity and simplification (especially for small projects and the adoption of simplified costs).

- LEADER Projects responding to COVID-19: A newsletter produced by Rural Perth \& Kinross LEADER (Scotland, $\mathrm{UK}$ ) in response to the coronavirus presenting some interesting projects, incl. the use of 3D printers.

- Survey on food behaviour and COVID-19: An independent European-wide initiative has set up a survey designed to grasp some important aspects of food behaviours during this pandemic period.

- ROBUST - Rural-urban relations in times of COVID-19: ROBUST - a H2020 project on rural-urban relations - has launched a blog on Rural-urban relations in times of COVID-19.

- Building rural resilience in a post-coronavirus economy - interview with Thomas Norrby: The expert in rural entrepreneurship Thomas Norrby from the Swedish Agricultural University discusses how communities can get out of coronavirus crisis stronger than ever.

- LEADER initiatives responding to COVID-19 in rural Spain: In rural Andalucia (Spain), Local Action Groups have promoted several initiatives to reduce the negative effects of the COVID-19 pandemic. For example, LAG Gran Vega de Sevilla has created a web with museum expositions, concerts and virtual trips to wonderful villages, offering entertainment and education to people during the confinement. LAG Guadajoz y Campiña Este developed a questionnaire for mapping the economic and social consequences of COVID-19. The Association 'El Avío' developed a social catering to help community members in need during the quarantine. The rural world is proving its capacity to resist and adapt in these uncertain times. And in this pandemic, LEADER and the Local Action Groups are proving to be an effective tool for channelling the needs of rural territories, energising the population and tackling new global challenges.

Support to employment in agriculture
- COVID-19: the 'Work Harvest' website for job placement in the agricultural sector: The aim of the project was to connect farmers and producers with potential employees. It is crucial for the agricultural sector to have an adequate number of workers available to prepare, care and harvesting the crops. To achieve this goal, a website called 'Work Harvest' has been set up under the Hungarian Rural Development Programme's (RDP) Technical Assistance to match agricultural companies offering work with jobseekers.

- Help the harvest - a Flemish initiative: The project is an initiative of the Flemish government and involves VDAB, the employment service of Flanders, and farmer organisations Boerenbond, ABS and Verbond Belgisch Tuinbouwveilingen. Farmer organisations promote the service among farmers, who communicate their vacancies at VDAB. VDAB then searches for suitable employees among job seekers, job students, retired workers or community workers. Farmers are asked to take the necessary precautions to ensure the well-being of their employees. 


\begin{tabular}{|c|c|}
\hline & $\begin{array}{l}\text { - Lend your arms to the French agricultural sector: Through an online platform, people who cannot work } \\
\text { due to the COVID-19 crisis but are able to help their communities can connect with farmers and offer } \\
\text { practical help (obviously respecting safety rules). } \\
\text { - Veneto (IT): Demo farms ease COVID-19 lockdown. As Italy eases COVID-19 lockdown, entering so- } \\
\text { called 'phase 2' of the confinement, some parents are going back to work but their children's schools } \\
\text { are still closed. Some farms in the Veneto region offer open-air activities for children. The initiative } \\
\text { is a collaboration of the local association of women farmers and rural entrepreneurs, Donne Impresa } \\
\text { Coldiretti Verona, with the regional project Educazione alla Campagna Amica, fostering children's } \\
\text { connection with, and understanding of, agriculture and rural areas. }\end{array}$ \\
\hline & $\begin{array}{l}\text { - Agricultural training in Flanders goes digital: To respond to the ongoing demand for training and } \\
\text { information from future and current farmers, the Flemish Minister of Agriculture gave agricultural } \\
\text { training centres the opportunity to offer online courses. } \\
\text { - A recovery plan for agriculture and horticulture in West Flanders: Support and inspire municipal services } \\
\text { and farms to develop shared initiatives. The agricultural research centre Inagro vzw has published a } \\
\text { small inspiration guide. In collaboration with a farmer organisation, the centre is planning to produce } \\
\text { instructional videos to train quickly seasonal workers (e.g. picking strawberries or mushrooms). They } \\
\text { also aim to support and facilitate farmers who want to bring their story to a wide audience via social } \\
\text { media, podcasts and articles. } \\
\text { - Modifying machinery to protect agricultural workers: Flemish agricultural research center INAGRO } \\
\text { vzw is helping farmers adapt their machinery to the new safety rules related to the COVID-19 crisis. } \\
\text { Videos on Facebook show how to adapt a potato planter machine to make sure workers are protected } \\
\text { and can respect social distancing rules. }\end{array}$ \\
\hline & $\begin{array}{l}\text { - Flemish flower growers: from competitors to partners. The Van Biesen rose plantation in Opwijk, } \\
\text { Flanders (Belgium) successfully joined forces with seven other flower growers to set up a webshop. } \\
\text { - An online platform dedicated to small producers in Romania: Romanian Ministry of Agriculture } \\
\text { and Rural Development (MARD) launched an online platform where small producers can post their } \\
\text { available amounts of vegetables and agricultural products. This enables them to support and provide } \\
\text { for each other and, at the same time, it facilitates the dialogue with large retail chains, in order to fill in } \\
\text { the gaps generated by the COVID-19 crisis. } \\
\text { - Italian farmers delivering food at home: The Federation of Italian Farmers (CIA) has rganized a home- } \\
\text { delivery service of fresh agricultural produce for vulnerable people and people at risk during the } \\
\text { coronavirus crisis. Their website provides a list of farmers with updated contact details. } \\
\text { - Local responses to the COVID-19 crisis in Slovenia: An online map of farms selling food across the } \\
\text { country has been made available with support by Ministry of agriculture and national funding. } \\
\text { - Highlighting youth solidarity in rural Spain: The Youth Council of Extremadura (Spain) has created } \\
\text { an online 'Solidarity Map' to collect and share all the initiatives taken by local youth to help in the } \\
\text { COVID-19 crisis. }\end{array}$ \\
\hline
\end{tabular}


Support to rural communities and people in need
- An inspiring database for curious tourists in the Czech Republic: The National Network of Local Action Groups in the Czech Republic has launched a website showcasing and linking to small regional producers. This initiative supports local businesses and can inspire curious tourists to discover rural Czech Republic. The website 'Regiony sobě' ('Regions to themselves') offers a number of links to small regional producers in different regions of the Czech Republic. The companies listed focus on food and natural products, crafts, handicrafts, services, restaurants and accommodation, and have regional shops and stores. Users can also purchase a voucher to access products and services at a given time.

- Pioneers in rural Germany: An initiatives started in 2015 to collect experiences of people moving from urban centres to rural Germany is experiencing lots of success during the COVID-19 situation, with more and more people requesting advice to move to rural areas. The initiative Raumpioner Station Oberlausitz aims to "make the first step easier" for new settlers, providing first-hand accounts and direct contacts with people in Upper Lusatia, easter Germany. This happens through a blog, events and meetings. The activities have been supported also via LEADER funding through the LAG Östliche Oberlausitz.

- Sierra Norte Acción on COVID-19: A local action group set up the Acción Sierra Norte platform to protect the groups most at risk from the spread of COVID-19.

- Building from the community up: The Wales Rural Network is sharing initiatives by local agencies in Wales (UK) to face the challenges of the COVID-19 pandemic in rural areas.

- A 'talent bank' in rural Belgium: 'Talentenbank' - the 'talent bank' - is a LEADER project in Aarschot, in rural Flanders (Belgium) which matches local talents with needs in the community. The initiative has boomed during the COVID-19 crisis, fostering community solidarity. The talent bank has been working since 2012 . It was further developed during the pandemic, creating new functionalities to improve online activities and integration with online apps. For the municipality, the project was already well-known and widely used and has in these times of crisis it has helped maintain social contacts virtually.

- Swedish High Coast local communities' responses to COVID-19: The LAG Leader Höga Kusten is gathering information and tips on how companies and associations in its area (Sweden's High Coast) are adapting and helping their communities.

- COVID-19: Community Foundations in action: Reinder Witting, Chairman of the community foundation Twentse Noabers Fonds (the Netherlands), describes how the Fonds reacted to the COVID-19 crisis, fostering 'virtual' local connections to respect social distancing rules.

- The role of LEADER in the COVID-19 crisis in rural Italy: The Italian LEADER Network has published a report on LEADER's specific role to support rural areas through the COVID-19 pandemic.

- Solidarity initiatives in rural France - a collection: The French National Rural Network is gathering solidarity initiatives and perspectives from rural communities on its website. The page includes also tips and tools for remote working.

- Spain: fostering solidarity in rural areas in the COVID-19 crisis. LAGs and other rural development stakeholders in Spain have set up free services to help vulnerable people throughout the COVID-19 crisis. The LAG Collective for Rural Development Tierra de Campos in Castilla y León has set up a free phone line where expert therapists are available for people who need to talk to someone during the quarantine and struggle to manage their emotions in this extraordinary situation. This and other initiatives are listed on the website of the Collective for Rural Development in Castille and disseminated via Facebook. In Catalunia, Prats de Lluçanès Solidarity Exchange aims to foster community solidarity and encourages people in the community to call or video call other people living alone, so that their day-to-day life in the confinement period becomes less burdensome.

- Galway County Council (IE) co-ordinating local organisations in COVID-19 crisis: Galway Rural Development (Ireland) is sharing local community initiatives to support local communities in times of COVID-19 crisis. Local activities include a dedicated community support helpline available for free, as well as an inventory of Response Teams set up by local community groups and associations to provide help in their communities.

- Repository of responses to the COVID-19 crisis in France: In France an online platform 'Carrefour des innovations sociales' presents social innovation initiatives facing the COVID-19 crisis.

- French rural mayors in action against COVID-19: The Association of French Rural Mayors popularizes initiatives around rural France tacking the COVID-19 crisis. Activities range from community solidarity to support to local businesses and communication activities. The same website also allows the sharing of further initiatives.

- A network of Community Champions against COVID-19: The COVID-19 Community Outreach (CCO) initiative is coordinated by The Wheel and Irish Rural Link and funded by the Department of Rural and Community Development. It is a national response to the coronavirus regarding the societal impact.

- Rural responses to COVID-19 crisis - RURITAGE calls: sharing innovative actions increasing and strengthening resilience in rural communities.

- R.E.D. relays rural territories \& solidarity initiatives: Rurality - Environment - Development (R.E.D.) has decided, together with its partners in the European Countryside Movement, to contribute to the current solidarity impulses by relaying initiatives and calls from all actors of the rural territories. Beyond the concerns for the economic impact, they focus as well on other aspects such as the role of women and men who are mobilised in projects, associations, or small businesses, or the social bond between agriculture and food.

- ESPON is collecting experiences and evidence on local and regional responses to COVID-19: local and regional initiatives, experience of communities and best practices for monitoring the territorial impact of coronavirus crisis and development of adequate responses for the future.

- The European Committee of the Regions has launched an online exchange platform about COVID-19: An online exchange platform launched by the European Committee of the Regions about COVID-19 for its members, Presidents of regions, Mayors and other local and regional partners. 
Those are some interesting initiatives showing some inspiring solidarity examples and approaches to cope with emergency in rural communities across Europe. Below some other examples from Bulgaria are presented in connection to the most famous initiatives promoting local food and in the context of future challenges.

The festival "Made on the Farm" presents farms and small producers who make authentic food from natural products and traditional Bulgarian recipes: cheese, yellow cheese, yogurt, honey and bee products, jam, eggs, meat, seasonal fruits and vegetables, herbs, spices and more (Bioferma, 2020). All farmers and producers are registered according to the legislation on processing and direct sales. Most of them have been supported by a cooperation program of Bulgaria and Switzerland. There are many organic producers also. Twice the festival received support from Sofia Municipality under the Europe Program, and in 2019 it was awarded the "Europe" prize of Sofia Municipality in the category of project that has contributed to the socialization of urban spaces.

The festival is organized by Bioselena Organic farming Foundation (Bioselena Organic farming Foundation, 2020). The main mission of BIoselena is to contribute to the development of organic and sustainable agriculture and through advocacy and lobbying to provide real a political support and effective access to European and national programs. Among its goals are:

- Development of modern regulations and measures to support the production and consumption of organic food;

- Provision of high quality services - consulting and training of organic farmers and processors and introduction of innovations throughout the food chain;

- Supporting and promoting short supply chains and ensuring better access of organic and artisanal foods to local markets;

- Increasing the incomes of farmers in the mountainous regions of Bulgaria and promoting sustainable use of natural resources;

- Promotion of organic and sustainable agriculture and production among producers, processors, traders, consumers and politicians;
- Building effective marketing chains and operational groups for interaction, involving all stakeholders from production to final consumption, such as short supply chains and farmers' associations;

- Innovations in agriculture in order to modernize production and increase producers' incomes;

- Building a network for training and consulting and providing professional and quality training and advice.

In time of COVID-19 the festival has experienced a number of difficulties as Stoilko Apostolov from Bioselena shared in an interview (Stoilko Apostolov from Bioselena, 2020). Following the beginning was in 2008, when together with several Bulgarian NGOs the coalition "Clean food - honest livelihood" was formed, which fought for a change in the legislation allowing Bulgarian farmers to sell directly to the end customer, via the period 2013 - 2017, with the help of the Swiss program Bioselena helped many Bulgarian farmers to build small sites for processing milk, meat, honey, fish and sell legally, the first craft and farm processing sites were registered in 2015. From June 2017 Bioselena organizes two farmers' markets one of which every Wednesday in front of the building of the Ministry of Agriculture in the capital city of Sofia. There are 55 producers (farmers and craftsmen) in the markets with 329 products, of which 166 are certified for organic production. Farmers manage 8,000 acres of land, raise 658 animals and 760 hives. The producers are from different regions of the country.

Mr. Apostolov said that the crisis hit the festival very hard because in the early March all municipal and farmers' markets were closed by order of the Ministry of Health. The main motive was the crowding of many people and the lack of distance. Because they work in a European network and have been able to gather information very quickly on the measures that are being taken in other European countries that are much more severely affected by the coronavirus, they found that only 2-3 countries had temporarily closed farmers' markets. This helped them a lot in the negotiations with the Ministry of Health and the Ministry of Agriculture and Food which reacted quickly and adequately and supported their request for the farmers' markets to be open. Thus, after about 40 days of forced closure, the market reopened on April 22 but "nothing was the same as before". Not only the fear among people but also the necessary measures and new requirements to 
producers selling food changed the festival as a whole. You can see some pictures from the site of the festival: http:/ / bioferma.org/ (Fig. 4).

Pictures 1 - 4. The changes in The Farmers' Market of Bioselena In Times Of COVID-19

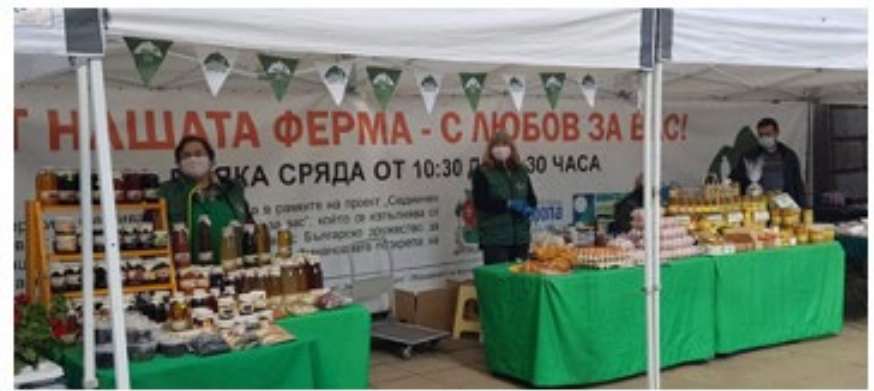

$29 / 04 / 2020$

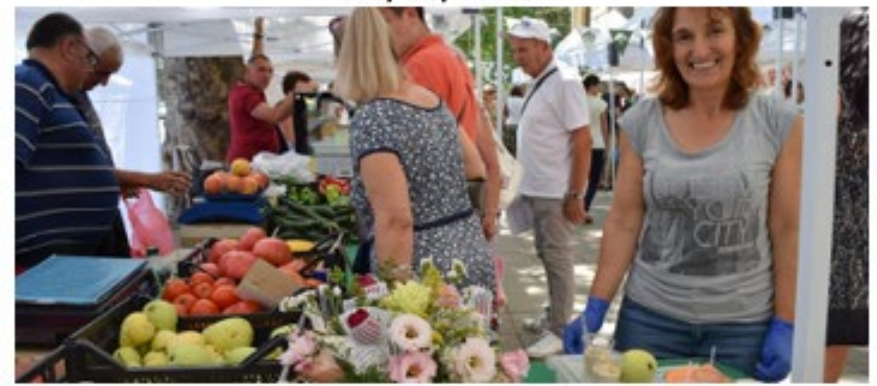

$07 / 08 / 2019$

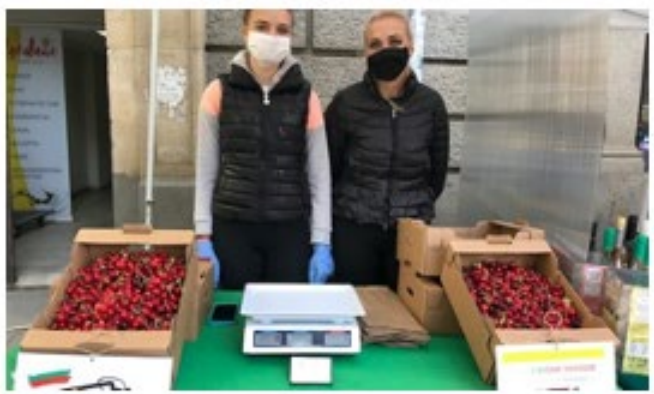

$13 / 05 / 2020$

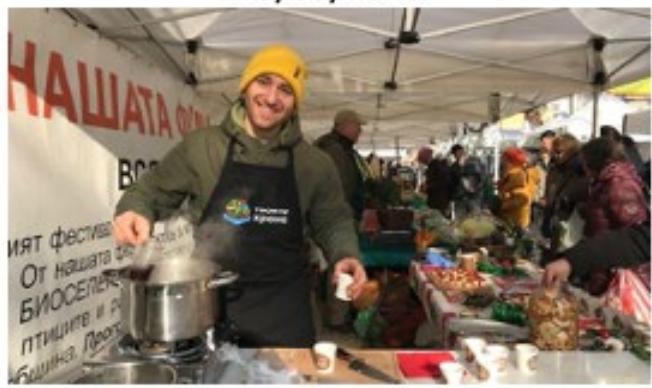

$02 / 01 / 2020$

As Mr. Apostolov said another form of short chains is the direct delivery of food to the home or workplace, but at the moment this is legally possible only in Sofia and maybe in 2-3 more cities where there are specialized food delivery companies. There is likely to be a significant expansion of this segment very soon.

One prominent example is the platform "farmhopping" which is an online farmers' market for sustainable producers (Farmhopping, 2020). In fact the original idea to support small family farmers was evolving and growing, and now farmhopping is an online farming market with over 100 farms producing clean produce that is available to people in the city through the online farmhopping.com platform.

Farmers receive a fair wage and consumers a convenient supply of real and fresh food throughout the country. And customers in Sofia can also shop from a store where various events, tastings and meetings with producers every week are organized. There is also a restaurant and all recipes in the restaurant menu are prepared with farm products from the online platform. The main idea of the founders is to further develop and acquaint more and more people with the ideology of farmhopping, as well as to raise the standard of living of customers through the consumption of clean and quality products. The platform is out of stock - what is ordered is still produced by the farms and arrives to the customer within 48 hours. In this way, in addition to ensuring the freshness of the products, food waste is also avoided. The focus is on seasonal, naturally produced products, so a prerequisite for producers is not to use pesticides, preservatives and improvers and to follow the requirements for sustainable agriculture.

In the spring of 2020 farmhopping became part of the SIS Coop Cooperative (SIS Coop Cooperative, 2020). It is an organization working on the principle of mutual assistance of its members in carrying out and upgrading their activities. It specializes in identifying, supporting and financing the needs of its cooperators - farmers, breeders and craftsmen. It has 26 regional offices throughout the country, with over 40 associates. The team of the Cooperative consists of proven specialists in the field of agriculture, animal husbandry, project development, lending and insurance. Today, the company continue to work for the farmhopping mission of supporting small and family farms and providing the city man with convenient access to clean food produced with care for nature and the health of the family. 
Another good example is the Farmers' Market "Pendara" in Plovdiv stared as an initiative of LocalFood.BG Foundation (LocalFood.bg, 2020) wellexperienced in promoting local food throughout years with a number of activities and projects for farmers and producers, food marketing and trainings.

\section{Picture 5. A picture from the facebook profile of Pendara Market (13/11/2020)}

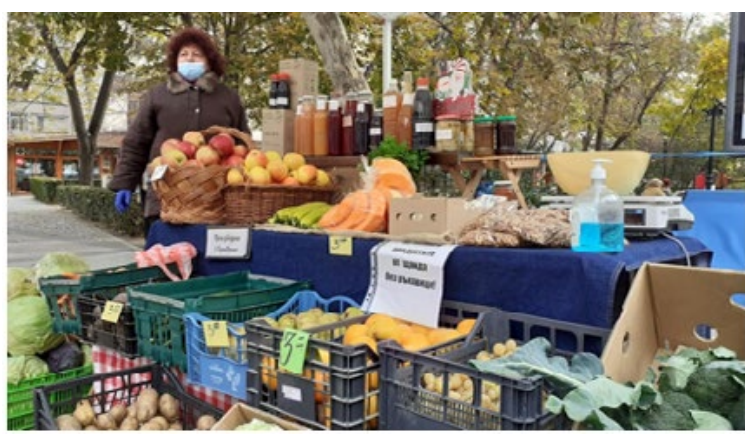

Now the market is active online (Pendara Markets, 2020) and developed a strong campaign in facebook (Pendara Farmers' Market, 2020) with a special focus on an initiative "Food against viruses".

\section{CONCLUSION}

The shift to a fair, healthy and environmentallyfriendly agri-food system can have environmental, health and social benefits and it can also provide economic advantages. The Farm to Fork Strategy and the European Green Deal, along with the new CAP, will provide new opportunities for all the operators in food chain, and particularly for the farmers. The key elements are connected to generating fairer economic returns and competitiveness. This is especially important in times of the COVID-19 pandemic or other crises of economic downturn when the food quality and safety gains even more attention in the context of the health protection. In that situation the response of farmers and communities is very important providing some good examples of coping with the emergency and actions of solidarity and support to short food supply chains, information provision and awareness, employment in agriculture, volunteering and new thinking, online training, online markets and direct sales, rural communities and people in need, networking, etc. The process of the transition to sustainable agri-food systems will require coordinated actions for advisory services, data and knowledgesharing, and skills; research and innovation, technology and investment; financial instruments, etc. in global plan to find solutions and reveal new opportunities for achieving more sustainable development.

\section{REFERENCES}

- A FARM TO FORK STRATEGY: FOR A FAIR, HEALTHY AND ENVIRONMENTALLY-FRIENDLY FOOD SYSTEM. (2020). Communication from the Commission to the European parliament, the Council, the European economic and social committee and the Committee of the regions, Brussels, 20.5.2020, COM (2020) 381 final, https: / / ec.europa.eu/food/farm2fork_en/ (Accessed Date:: 09/11/2020)

- ANALYSIS OF LINKS BETWEEN CAP REFORM AND GREEN DEAL (2020). Commission staff working document. Brussels. 20.5.2020. SWD(2020) 93 final.

- BIOSELENA ORGANIC FARMING FOUNDATION. https:// bioselena.com/ (Accessed Date:: 30/11/2020).

- EU AGRICULTURE IN NUMBERS. (2020). Performance on the nine specific objectives of the CAP> European Commission. Factsheet, May.

- EU BIODIVERSITY STRATEGY FOR 2030. https://ec.europa.eu/ info/strategy / priorities-2019-2024/ european-green-deal/actionsbeing-taken-eu/eu-biodiversity-strategy-2030_en (Accessed Date: 09/11/2020)

- EUROPEAN GREEN DEAL. https://ec.europa.eu/info/strategy/ priorities-2019-2024/european-green-deal_en/ (Accessed Date: 09/11/2020)

- FARM TO FORK STRATEGY. https://ec.europa.eu/food/sites/ food / files / safety / docs / f2f_action-plan_2020_strategy-info_ en.pdf/ (Accessed Date: 09/11/2020).

- FARM2FORK. https://audiovisual.ec.europa.eu/en/ video/I-196217/ (Accessed Date: 09/11/2020.

- FARMHOPPING. https://farmhopping.com/ (Accessed Date: 30/11/2020)

- FOOD LOSS AND WASTE PREVENTION. https:/ / ec.europa.eu/ food/farm2fork/ food-loss-and-waste-prevention_en/ (Accessed Date: $09 / 11 / 2020)$

- FROM FARM TO FORK: OUR FOOD, OUR HEALTH, OUR PLANET, OUR FUTURE. https://ec.europa.eu/info/strategy/ priorities-2019-2024/european-green-deal/actions-being-takeneu/farm-fork_en/ (Accessed Date: 09/11/2020).

- HOW THE FUTURE CAP WILl CONTRIBUTE TO THE EU GREEN DEAL. https://ec.europa.eu/info/sites/info/files/ food-farming-fisheries/sustainability_and_natural_resources / documents / factsheet-how-cap-contributes-to-green-deal_en.pdf/ (Accessed Date: 09/11/2020).

- INTEGRATED FOOD SAFETY POLICY IN THE EU. https:// ec.europa.eu/food/overview_en/ (Accessed Date: 09/11/2020).

- KEY POLICY OBJECTIVES OF THE FUTURE CAP, https:// ec.europa.eu/info/food-farming-fisheries / key-policies / commonagricultural-policy / future-cap/ key-policy-objectives-future-cap_ en\#nineobjectives/ (Accessed Date: 09/11/2020).

- LOCALFOOD.BG. https://www.localfood.bg/ (Accessed Date: $30 / 11 / 2020)$

- MADE ON THE FARM. http://bioferma.org/ (Accessed Date: $30 / 11 / 2020)$

- MODERNIZING AND SIMPLIFYING THE CAP. (2020a). Background Document. Economic challenges facing EU agriculture, EU.

- MODERNIZING AND SIMPLIFYING THE CAP. (2020b). Background Document. Climate and Environmental challenges facing EU agriculture and rural areas, EU. 
- MODERNIZING AND SIMPLIFYING THE CAP. (2020c). Background Document. Socio-Economic challenges facing EU agriculture and rural areas, EU.

- PENDARA FARMERS' MARKET. https://www.facebook.com/ fermerskipazarplovdiv/ (Accessed Date: 30/11/2020).

- PENDARA MARKETS. https://market.pendara.bg/ (Accessed Date: 30/11/2020).

- RURAL RESPONSES TO THE COVID-19 CRISIS. https://enrd. ec.europa.eu/rural-responses-covid-19-crisis_en/ (Accessed Date: 09/11/2020).

- SIS COOP COOPERATIVE. http://siscoopbg.com/ (Accessed Date: $30 / 11 / 2020)$.

- STOILKO APOSTOLOV FROM BIOSELENA: THE FARMERS' MARKET HAS LOST ITS CHARM FOR THE CLIENTS BECAUSE OF THE MEASURES. https://www.capital.bg/biznes/ kompanii / 2020/08/08/4100153_stoilko_apostolov_ot_bioselena_ fermerskiiat_pazar/ (Accessed Date: 30/11/2020).

- SUPPORTING THE AGRICULTURE AND FOOD SECTORS AMID CORONAVIRUS. https: / / ec.europa.eu/info/food-farmingfisheries/farming/coronavirus-response_en/ (Accessed Date: $09 / 11 / 20209$.

- SUSTAINABLE AGRICULTURE IN THE EU. https://ec.europa. eu/info/food-farming-fisheries/sustainability/ (Accessed Date: 09/11/2020).

- SUSTAINABLE FOOD CONSUMPTION AND FACILITATING THE SHIFT TOWARDS HEALTHY, SUSTAINABLE DIETS. https: / / ec.europa.eu / food / farm2fork/ sustainable-foodconsumption-and-facilitating-shift-towards-healthy-sustainablediets_en/ (Accessed Date: 09/11/2020).

- SUSTAINABLE FOOD PROCESSING, WHOLESALE, RETAIL, HOSPITALITY AND FOOD SERVICES. https://ec.europa.eu/ food / farm2fork / sustainable-food-processing-wholesale-retailhospitality-and-food-services_en/ (Accessed Date: 09/11/2020).

- SUSTAINABLE FOOD PRODUCTION. https://ec.europa.eu/ food/farm2fork/sustainable-food-production_en/ (Accessed Date: 09/11/2020.

- THE FUTURE OF CAP. https: / / ec.europa.eu/info/food-farmingfisheries / key-policies / common-agricultural-policy/future-cap_ en/ (Accessed Date: 09/11/2020).

- WHITE PAPER ON FOOD SAFETY. https://eur-lex.europa.eu/ legal-content/EN/TXT/?uri=CELEX:51999DC0719/ (Accessed Date: 09/11/2020). 